\title{
Encouraging Freshmen to Read
}

Mr. Johnson has served as chairman of the Freshman Reading Committee of the English faculty of the University of Illinois.

$\mathrm{E}$ Very student in Freshman Rhetoric at the University of Illinois must read at least three books supplementary to his regular assignments each semester. $\mathrm{Al}$ though instructors have the privilege of recommending books, the supplementary books are usually selected by approximately three thousand freshmen from the list prepared by members of the rhetoric staff and annually revised by a committee of instructors. (In a few experimental sections, the books for outside reading must be purchased by the student.) The books are shelved in a room set aside in the university library as a freshman reading room.

For many years the members of the rhetoric staff have insisted that one of the important aims of the course is to encourage intelligent student reading. Until 1926, the supplementary books were arbitrarily selected by the staff without permitting the student any choice. In 1926-1927, a list of 547 titles, from which the student chose six books during the year, was prepared and printed in the Rhetoric I and 2 Manual and Calendar. Although the extended list gave the student some measure of choice, he still could not examine the books themselves, for they were shelved in stacks closed to under- graduates. In 1931-32, the books were placed on reserve, but not until October I, I937, was the student able to examine the books before making his selections. At that time, the Freshman Reading Room was opened.

The reading list ${ }^{1}$ consists in 1940-194I of 1146 titles, divided into these sections:

Autobiography and biography . .147

Travel ................... I4I

Popular science ........... 77

The arts $\ldots \ldots \ldots \ldots \ldots \ldots$. 50

Essays $\ldots \ldots \ldots \ldots \ldots \ldots . \ldots 58$

Social points of view . ....... 67

Contemporary prose fiction .... I79

Standard prose fiction ...... 129

Short stories $\ldots \ldots \ldots \ldots \ldots, 58$

Drama ................. 48

Poetry ............... 92

Selected to appeal to students who vary greatly in training, backgrounds, interests, and ability, the books on the list are obviously varied. For this reason, certain sections of the list are divided into three subsections: (a) books that students who have read widely are likely to enjoy; (b) books that students who have read somewhat are likely to enjoy, and (c) books that students who have read little are likely to enjoy. To help the student still further, the committee has divided the

\footnotetext{
1 The list is published in the Rhetoric $I$ and 2 Manual and Calendar for 1940-1941, which can be obtained through the Illini Union Bookstore, Champaign. The collection consists of approximately two phound volumes; many of these are duplicates, of course.
} 
popular science and arts sections according to subject matter. The popular science list is divided into these subsections: the stars and the universe; physics-matter and energy; the earth-geology and geography ; man-anthropology, archeology, etc.; animals, birds, fish, insects, plants; applied science; and surveys of scientific thought. The arts list is divided into subsections on aesthetics, architecture, dancing, industrial design, movies, music, painting, and primitive art.

\section{Revision of Reading List}

Each year a committee of instructors is appointed to consider the revision of the reading list. Before any final decisions are made, all the members of the staff are asked to offer suggestions for adding new books and for removing old ones. Then the librarians are consulted for suggested changes. As they have kept a circulation record for each book and get a fairly reliable impression of student reactions, their suggestions are particularly valuable. After having weighed these suggestions, and after having considered as many new books as possible, the committee makes its revision. As a guide in adding new books, the committee uses the late Professor B. L. Jefferson's statement of principles controlling the selection of new books:

I. To lead students from adventure books, pure and simple, to travel books of the ordinary kind, to travel books with philosophical or artistically presented contents.

2. To lead from books that discuss our own type of civilization to books that deal with older or distant types of civilization.

3. To begin with biographies of men and women who have succeeded in work similar to that in which students are interested and to lead to biographies of men and women unlike the students.

4. To capitalize their interest in motion pictures by giving them dramas and novels from which motion pictures have been made.

5. To use Illinois poetry and simple poetry of American life as an introduction to other poetry.

The books in the collection are shelved in the Freshman Reading Room, known as the Seven-Day Book Room, an arrangement which permits the student to examine the books before he decides to read a particular one. From the point of view of the librarians, the room is an experiment in open shelving. From the point of view of the rhetoric instructors, it is a means of giving the student the opportunities of becoming acquainted with a collection of carefully selected books and of exercising, within the limits of a fairly extensive collection, freedom of choice.

The room is equipped with three reading tables, eighteen chairs, a bulletin board, a desk, and open shelves with a capacity of two thousand volumes. It is supervised by two members of the library staff who keep a careful record of the circulation of the books and also supplement the guidance given the students by their rhetoric instructors. The librarians have also arranged attractive exhibits, which have called the attention of the students to books dealing with current topics and to books which undergraduates would be likely to overlook. The librarians have also supplied a number of reference books.

Since the room is open from 9 to 12 A.M. and from 2 to 5 P.M. on the first five school days of the week and from 9 to 12 A.M. on Saturdays, and from 7 to IO P.M. Monday through Thursday, adequate time is granted the student to make use of the collection. The student is permitted to take out each book for a period (Continued on page 145) 
some instances there were joint meetings of faculty representatives of departments to determine an intelligent and practical division of fields in which library collections were to be developed.

This program could very easily be expanded to include four or five other col-

\section{Encouraging Freshmen to Read}

(Continued from page 125)

of seven days. According to the records kept by the librarians over a number of years, an average of about seventy-five students withdraw books daily.

The expense for equipping and operating the Freshman Reading Room exclusive of the cost of processing and servicing the books, has amounted to \$I 8 Io: furniture (desk, shelves etc.) \$3IO; books purchased in 1937) \$800; and books (purchased since I937) \$700. In the spring of I940, the committee selected IOI books for addition to the collection and added 20 additional copies of books already on the list.

\section{Students Benefit More}

The exact measurement of the values of a freshman reading room is impossible, no doubt, but, since the opening of the room, most of us who are members of the rhetoric staff have felt that students have benefited much more from their supplementary reading than they did in the old days before they had direct access to the books and had to make their selections without the privilege of examination. Among other valuable results generally agreed upon by the older instructors are: leges and universities located within a fifty mile radius. A beginning along this line has already been made at the University of North Carolina where a joint cata$\log$ of all books of a research nature found in North Carolina libraries is being collected.

I. The freshmen approach their supplementary reading much more favorably than they used to.

2. More freshmen are reading books from the collection in addition to the minimum requirement of three per semester.

3. Better book reviews appear more often.

4. The Freshman Reading Room has served as an introduction to the facilities of the library to many of our students.

The problem of supplementary reading has always been difficult, as every instructor knows and the results are frequently unsatisfactory. Yet there are few instructors who do not believe it is worth while.

At the University of Illinois, the problem of supplementary reading has been at least partially solved through the successful operation of the Freshman Reading Room. Much of the credit for what has been accomplished must go to the members of the library staff who have not only granted the requests made by our staff but have also cooperated enthusiastically in our attempt to encourage freshmen to read. 